\title{
FACTORS INFLUENCING THE PURCHASE OF ENERGY-EFFICIENT APPLIANCES BY YOUNG CONSUMERS IN SOUTH AFRICA
}

\author{
Olawale FATOKI \\ University of Limpopo, Department of Business Management, Polokwane, SOUTH AFRICA \\ e-mail: olawale.fatoki@ul.ac.za
}

\begin{abstract}
Household appliances are the biggest contributor to household energy consumption and carbon dioxide emissions. One of the ways to reduce emissions and conserve energy is to increase the use of energy-efficient appliances (EEAs). Based on the theory of planned behavior (TPB), the study investigated the factors that influence the purchase of EEAs by young consumers in South Africa. Young customers are the customers of tomorrow and can help to prevent global ecological collapse through sustainable consumption. The study extended the TPB by adding two individual constructs (moral norms and environmental concern) and two situational constructs (informational publicity and perceived benefits). In addition, the study examined the effect of purchase intention on purchase behavior. The cross-sectional survey method was used for data collection in the quantitative study. Data was collected from final year undergraduate students at two South African universities. The results indicated that the extended TPB model can be used to predict the purchase intention of EEAs. Also, purchase intention positively affects purchase behavior. Theoretically, the study extended the TPB to create a unique model of intention to purchase EEA. Practical suggestions focus on what business and government should do to improve the purchase of EEA.
\end{abstract}

Keywords: energy-efficient appliances, theory of planned behavior, young customers, South Africa.

JEL Classification: M10, M13, M14, M31.

\section{Introduction}

Consumption is a major economic and social activity, and household consumption as a percentage of the global gross domestic product was $63.64 \%$ in 2018 (World Bank, 2019). This high level of consumption by households has led to the massive depletion of resources, pollution, and loss of biodiversity (Paddock, 2017). Human needs for natural resources have doubled in the past 50 years, with negative environmental impact and environmental risks accounting for three of the five major risks by likelihood and four by impact according to the 2018 Global Risks Perception Survey (World Economic Forum, 2018). According to the World Wildlife Federation (2016), humans presently need the biocapacity of 1.6 Earths to accommodate the goods and services that are demanded each year and the present consumption pattern is unsustainable.

In addition, the world population is projected to reach 9 billion people by 2050, and this will further increase consumption and deplete resources. Also, global electricity demand increased by $4 \%$ in 2018 and in South
Africa, electricity generation increased by $2.2 \%$ between July 2017 and July 2018, while electricity consumption increased by $1.2 \%$ within the same period (Statistics South Africa, 2018; International Energy Agency, 2019). South Africa is one of the least energy-efficient nations and the 11th highest emitter of greenhouse gasses in the world. The reliability of electricity supply is under threat in South Africa, and the main energy supply company (Eskom) is unable to meet demand and rolling blackouts are common. Inadequate supply of electricity is hugely disruptive and negatively impacts on the economy (Department of Energy, 2019).

Household appliances are the biggest contributor to household energy consumption, and around 70\% of household carbon dioxide emissions come from household appliances (International Energy Agency [IEA], 2016). The high rate of household consumption of energy yields negative externalities such as climate change, nuclear disasters, and over-reliance on costly fuel importation, especially by countries that do not produce petroleum (Stadelmann, 2017). 
One of the ways to reduce emissions and conserve energy is to increase the purchase and use of energy-efficient appliances (EEAs) (Hua and Wang 2019; Wang, et al., 2019). Goals 7 and 12 of the sustainable development goals call for a secure access to affordable, reliable, sustainable, and modern energy and sustainable production and consumption (United Nations, 2019). The South African government is encouraging energy conservation in all the sectors of the society through the National Energy Efficiency Campaign and energy efficiency (EE) ratings, and by law, all household appliances are mandated to display labels that accurately show their EE. However, the level of awareness of EE campaign is low in South Africa and this is one of the major implementation barriers of energy conservation (Tholen, et al., 2015). Therefore, it is important to understand the factors that can promote the use of EEAs in South Africa.

The theory of planned behavior (TPB) is the most frequently used theory to predict pro-environmental intentions and behaviors ( $\mathrm{Ru}$, et al., 2018). The TPB by Ajzen (1991) contends that the performance of a specific behavior by an individual is determined by the intention to perform the behavior. The behavioral intention of an individual is determined by three factors, which are attitude, subjective norms and perceived behavioral control. According to Chen and Tung (2014), the explanatory power of the TPB can be improved by the inclusion of additional constructs. This study extended the TPB by adding two individual constructs (environmental concern and moral norms) and two situational constructs (informational publicity and perceived benefits) to develop a model of purchase intention for EEAs. Empirical research (Ng, et al., 2018; Huang and Ge, 2019) argues that many factors influence the intention to purchase environmentally friendly products. This study aims to develop an EEA purchase intention model that extends the TPB from the perspective of young customers in South Africa.

The study will be significant in the following ways. First, EEA purchase intention and behavior is an emerging area of research especially in developed countries; however, to the best of the author's knowledge, this is the first study from the South African perspective. Second, the study intends to develop a theoretical model of EEA purchase intention that extends the TPB by incorporating both individual and situational factors. Third, the study examines if purchase intention actually affects purchase behavior, and fourth, the study focuses on young consumers (university students) who are expected to drive sustainable consumption in the future.

In addition, as pointed out by Maistry and McKay (2016), universities in South Africa face the challenge of escalating energy costs and are expected to provide leadership by being exemplars of energy efficiency. Therefore, the reduction of energy consumption by university students is expected to cascade down to parents, households, and businesses. The study is organized as follows. Section 2 provides a review of the literature and the development of the conceptual framework and hypotheses. Section 3 focuses on the research methodology and measures. Sections 4 and 5 present the results and discussion, respectively. The conclusion, implications, limitations, and areas for further study are presented in Section 6.

\section{Literature Review}

\subsection{Energy efficiency and energy efficient appliances}

Shove (2018) pointed out that energy efficiency (EE) can be described as the use of a lower amount of energy to produce the same amount of a product or service. According to the World Energy Council (2013), EE embraces all changes that lead to the reduction of energy used for a given service or level of activity. EE includes behavioral, economic, and technological changes, and is associated with economic efficiency. The benefits of EE include the reduction of waste through the use of a lower amount of energy to execute the same task, reduction of the demand for energy and greenhouse gas emissions, and lowering of households' and country-level costs associated with energy consumption (Environmental and Energy Study Institute, 2019). A global shift to EEAs will reduce worldwide electricity consumption by more than $10 \%$ and $\$ 350$ billion annually in electricity costs and reduce global carbon dioxide emissions by 1.25 billion tonnes yearly (United Nations Environment Programme, 2014). Energy efficient appliances (EEAs) include air-conditioners, light bulbs, washer dryers, 
fridges and freezers, washing machines, water heaters, tumble dryers, electric ovens, and dishwashers (Department of Energy, 2019).

\subsection{TPB and EEA purchase intention}

\section{- $\mathrm{TPB}$}

The TPB extends the Theory of Reasoned Action by Fishbein and Ajzen (1975) and Ajzen and Fishbein (1980) and argues that the performance of a specific behavior by an individual is determined by the intention, which depends on attitude, subjective norms and perceived behavioral control (Ajzen, 1991). The TPB has been used by many empirical studies in predicting behavioral intention in in the context of pro-environmental behavior (Chen and Tung, 2014; Wang, et al., 2016) and EEA research (Hua and Wang 2019; Wang, et al., 2019; Ali, et al., 2019).

- Attitude and EEA purchase intention

Attitude toward a behavior measures the degree to which an individual has a favorable or an unfavorable evaluation of the behavior being measured. A more favorable attitude toward a behavior should produce stronger individual intentions to perform the behavior (Ajzen, 1991; Dickinger and Kleijnen, 2008). Ha and Janda (2014) reported that the attitude toward an energy-efficient product has a strong effect on intention to purchase the product. If consumers have a positive attitude about EEAs, they will probably purchase them; otherwise, they will have no interest (Hua and Wang, 2019). Studies such as Wang, et al. (2019) and Akroush, et al. (2019) found that attitude toward green products positively affects purchase intention. A more favorable attitude by an individual should lead to a stronger intention to purchase EEAs.

Consequently, it is hypothesized that: (H1) There is a significant positive relationship between consumers' attitude and EEA purchase intention.

- Subjective norms (SNs) and EEA purchase intention

Subjective norms (SNs) describe an individual's feelings of social pressure from other people or group and measure the likelihood that important individuals or groups will like or dislike the performance of a certain behavior (Ajzen, 1991; Tan, et al., 2017). Empirical findings are inconclusive about the effect of SNs on the purchase of environmentally friendly products. Ha and Janda (2012) and López-Mosquera, et al. (2014) reported that SNs have a positive impact on EEA purchase intention. Arvola, et al. (2008) and Tan, et al. (2017) found that SNs do not have a significantly positive relationship with the purchase intention for EEAs and the lack of a relationship suggests that customers may not be easily influenced by the opinions of other people. The opinions of an important person or group may influence the intention of an individual to purchase EEA.

It is hypothesized that: (H2) There is a significant positive relationship between SN and EEA purchase intention.

- Perceived behavioral control (PBC) and EEA purchase intention

Perceived behavioral control (PBC) can be described as the perceived difficulty or ease of conducting a behavior. Factors such as opportunity, knowledge, and skill may affect the behavior of an individual (Ajzen, 1991; Chen and Tung, 2014). Ali, et al. (2019) reported that $\mathrm{PBC}$ positively influences consumers' intentions to purchase green products. Hua and Wang (2019) found that the availability of knowledge and skill in respect of EEA should positively influence the intention to purchase EEAs. If consumers think they have the knowledge and skill to use EEAs, they will be more willing to purchase them.

It is hypothesized that: (H3) There is a significant positive relationship between $\mathrm{PBC}$ and EEA purchase intention.

\subsection{Extending the TPB}

Ajzen (1991) and Chen and Tung (2014) pointed out that the power of the TPB can be improved by the inclusion of additional constructs as long as the new variables can be shown to improve the explanatory power of the model. Frederiks, et al. (2015) pointed out that the predictors of household energy consumption include: (1) individual factors which can be divided into two, that is, sociodemographic factors (age, gender, education) and psychological factors (knowledge/awareness, values, beliefs and attitudes, personal and moral norms) and (2) situational predic- 
tors (laws, regulations and policies, perceived benefits, technology, pricing, information, mass media, and advertising).

Individual factors are a product of an individual's experiences and can affect his/her decision-making process, and situational factors symbolize situational forces that can encourage or discourage the purchase of green products by individuals (Joshi and Rahman, 2015). Chaudhary and Bisai (2018), in a study on the factors influencing green purchase behavior of millennials in India, extended the TPB by examining environmental concern and willingness to pay as a moderating factor. Ali, et al. (2019), in a study on the factors affecting EEA purchase intention, extended the TBP by adding knowledge (individual) and price (situational), while Wang, et al. (2014) used energy knowledge, demographic variables, living habit, and information publicity to extend the TPB. This study will extend the TPB by adding individual factors (environmental concern and moral norms) and situational factors (information publicity and perceived benefits).

- Moral norms and EEA purchase intention

Moral norms can be described as the perceived moral obligation or responsibility to perform or not to perform certain task and represent an individual's belief that acting in a certain way is essentially right or wrong (Kaiser, 2006; Cheng and Tung, 2014). Moral norms have been used to extend the TPB in studies on energy-saving behavior, and the inclusion of the construct has improved the theory's explanation power (Chan and Bishop, 2013; López-Mosquera, et al., 2014). Petschnig, et al. (2014) and Shalender and Sharma (2019) used moral norms to extend the TPB in studies on the adoption intention of energyefficient products and found a significant positive relationship.

The findings are consistent with those of Tan, et al. (2017) in that moral norms have a significant positive effect on consumers' purchase intention of EEAs. Moral obligation by an individual to conserve natural resources and improve the environment can stimulate the intention to purchase EEAs.

Consequently, it is hypothesized that: (H4) There is a significant positive relationship between moral norms and EEA purchase intention.
- Environmental concern and EEA purchase intention

Environmental concern can be described as the extent to which an individual is aware of environmental problems, supports efforts to solve them, or indicates a willingness to contribute individually to provide solutions (Dunlap and Jones, 2002; Dagher and Itani, 2012). Li, et al. (2019) reported that environmental concern is positively correlated with the willingness to purchase EEAs.

Consumers with environmental concern will have favorable attitudes toward eco-friendly products or services (Kim and Han, 2010: Aman, et al., 2012; Yadak and Pathak, 2016). Harris (2006), however, found that environmental concern does not directly affect proenvironmental behavior. Individuals who are more concerned about the environment should have a higher tendency to support energy efficiency activities.

It is hypothesized that: (H5) There is a significant positive relationship between environmental concern and EEA purchase intention.

- Perceived benefits and EEA purchase intention

Hidrue, et al. (2011) and Nosi, et al. (2018) pointed out that perceived benefits can positively affect the willingness to purchase environmentally friendly products. When consumers perceive that there are benefits to be obtained by purchasing a product, they will have a higher purchase intention.

Akroush, et al. (2019) found that perceived benefits positively affect consumer purchasing intentions of EEAs. O'Driscoll, et al. (2013), however, reported that the benefits of renewable energy systems do not affect their adoption intention and further investigations are needed to examine the relationship between perceived benefits and purchase intentions.

Choi and Han (2019) found that perceived benefits are not a sufficient motivator for the adoption of green practices by fashion manufacturers. However, when consumers perceive that there are benefits to be obtained from EEAs, they will have a higher purchase intention. 
It is hypothesized that: (H6) There is a significant positive relationship between perceived benefits and the purchase intentions of EEAs.

- Information publicity and EEA purchase intention

du Plessis (2015) remarked that on a daily basis, South Africans are bombarded with information in the print and electronic media about the importance of energy conservation and the use of energy efficiency measures in households and workplaces. Wang, et al. (2014) pointed out that one of the obstacles to the adoption of energy-saving behavior by consumers is the lack of sufficient knowledge. Wang, et al. (2014) found that information publicity positively affects behavioral intention toward green products. According to Qader and Zainuddin (2011), the media have made a significant contribution to the widespread dissemination of environmental concern and publicity can transform a specific environmental problem into a major public issue. The study by Qader and Zainuddin finds a significant positive relationship between media coverage and the purchase intention of green products. Chen, et al. (2018) reported that the media can facilitate the sharing of detailed information and promote the recognition of green products. Consumers are more likely to consider energy-saving products if they have access to information.

It is hypothesized that: $(\mathbf{H 7})$ There is a significant positive relationship between information publicity and EEA purchase intentions.

\subsection{Consumers' purchasing intentions and purchase behavior of EEA}

Green purchasing can be described as the purchase of environmentally friendly products and services and the avoidance of products and services that harm the environment. Green purchase intention denotes the willingness of consumers to purchase green products, while green purchase behavior epitomizes a complex form of ethical decision-making behavior, which can be considered a type of socially responsible behavior (Ramayah, et al., 2010; Joshi and Rahman, 2015; Jaiswal and Kant, 2018). Kumar, et al. (2017), Jaiswal and Kant (2018), and Bhutto, et al. (2019) found a significant positive relationship between purchase intention and purchase behavior of environmentally friendly products. A strong intention towards the purchase of a green product can lead to actual purchase and consumption.

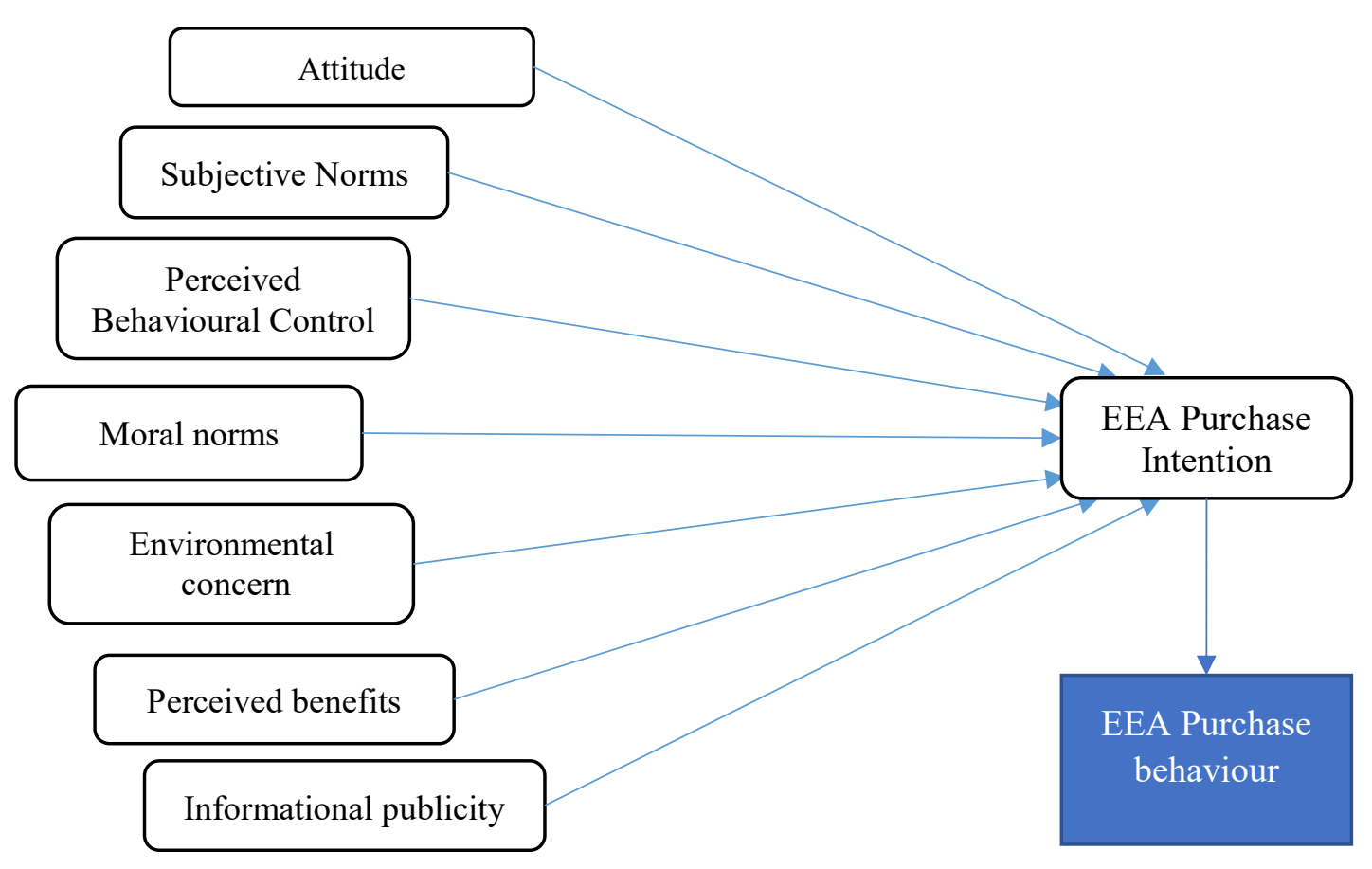

Figure 1. Conceptual framework (Source: Author's own research) 
It is hypothesized that: (H8) There is a significant positive relationship between purchasing intentions and consumer purchasing behavior.

Fig. 1 depicts the hypothesized research model.

\section{$3 \quad$ Research Methodology}

This study followed the quantitative research design, and the cross-sectional survey approach was used to collect data from the respondents. The participants in the survey were final year undergraduate students of the Departments of Business Management of two universities located in the Limpopo and Gauteng provinces of South Africa. University students can be considered as young customers because of their age (Choudhury and Dey, 2014). The participants were conveniently sampled, and the self-administered questionnaire method was used to collect data. Questionnaires were distributed in the class with the assistance of lecturers. The questionnaire was reviewed by two academic experts in the areas of marketing and sustainability and also pretested on 30 students. Minor adjustments were made to the questionnaire based on the feedback from the reviewers and the pilot study. The questionnaire was divided into three sections: (1) biographical details; (2) determinants; and (3) purchase intention and behavior. Descriptive analysis and the Partial Least Square Structural Equation Modeling (PLS SEM) were used for analysis.
Measures: Scales with acceptable psychometric properties were adapted for all the constructs from previous studies on environmentally friendly products. Attitude was measured on semantic differential scale, and the five-point Likert scale was used to measure the other constructs of the study. The questionnaire items are presented in Appendix A.

\section{$4 \quad$ Results}

\subsection{Response rate and biographical details}

Three hundred and twenty-five questionnaires were distributed and 298 questionnaires were returned and found usable. The gender composition of the respondents was 53\% female and $47 \%$ male. All the respondents were between 20 and 30 years. Independent samples T-test did not indicate any significant gender difference in the results.

\subsection{Descriptive analysis}

Table 1 depicts the results of the descriptive statistics. Kolmogorov-Smirnov test $(p>0.05)$ for the constructs assured the normality of the data. The results indicated that eight variables (attitude, perceived behavioral control, environmental concern, moral norms, perceived benefits, informational publicity, intention, and behavior) have means above. On a fivepoint Likert scale, a mean value below 3 is considered as low, 3-4 as moderate, and above 4 as high.

Table 1. Descriptive statistics (Source: Author's own research)

\begin{tabular}{|c|c|c|c|}
\hline Construct & Mean & $\begin{array}{c}\text { Standard } \\
\text { deviation }\end{array}$ & $\begin{array}{c}\text { Kolmogorov- } \\
\text { Smirnov }\end{array}$ \\
\hline Attitude & 4.10 & 1.06 & 0.175 \\
\hline Subjective norms & 2.75 & 1.18 & 0.102 \\
\hline Perceived behavioral control & 3.80 & 1.03 & 0.127 \\
\hline Environmental concern & 4.10 & 1.05 & 0.133 \\
\hline Moral norms & 3.98 & 1.15 & 0.127 \\
\hline Perceived benefits & 4.15 & 1.09 & 0.121 \\
\hline Informational publicity & 4.02 & 1.02 & 0.125 \\
\hline Intention & 4.05 & 1.01 & 0.127 \\
\hline Behavior & 3.10 & 1.09 & 0.116 \\
\hline
\end{tabular}




\subsection{Structural equation modelling}

The Partial Least Square Structural Equation Modelling (The PLS SEM) was used to examine the research model by using the software package Smart PLS 3.0. The PLS SEM is a strong and extensively used method to examine latent variables and can process complicated models without distributional assumptions for the sample (Chin, 1998). The PLS SEM comprises two sub-models and these are the measurement and structural models (Hair, et al., 2019).

Table 2. The measurement model (Source: Author's own research)

\begin{tabular}{|c|c|c|c|c|c|}
\hline Construct & $\begin{array}{c}\text { Measurement } \\
\text { items }\end{array}$ & Item loading & $\begin{array}{c}\text { Cronbach's } \\
\text { alpha }\end{array}$ & $\begin{array}{l}\text { Composite } \\
\text { reliability }\end{array}$ & AVE \\
\hline \multirow[t]{4}{*}{ Attitude (A) } & A1 & 0.782 & 0.739 & 0.875 & 0.636 \\
\hline & A2 & 0.826 & & & \\
\hline & A3 & 0.805 & & & \\
\hline & A4 & 0.776 & & & \\
\hline \multirow[t]{3}{*}{ Subjective norm $(\mathrm{SN})$} & SN 1 & 0.827 & 0.721 & 0.792 & 0.655 \\
\hline & SN2 & 0.792 & & & \\
\hline & SN3 deleted & 0.479 & & & \\
\hline \multirow[t]{3}{*}{ Perceived behavioral control (PBC) } & PBC1 & 0.848 & 0.814 & 0.856 & 0.664 \\
\hline & $\mathrm{PBC} 2$ & 0.827 & & & \\
\hline & PBC3 & 0.769 & & & \\
\hline \multirow[t]{3}{*}{ Moral norms (MN) } & MN 1 & 0.899 & 0.727 & 0.881 & 0.737 \\
\hline & MN 2 & 0.836 & & & \\
\hline & MN 3 & 0.795 & & & \\
\hline \multirow[t]{4}{*}{ Environmental concern } & $\mathrm{EC} 1$ & 0.848 & 0.792 & 0.884 & 0.655 \\
\hline & $\mathrm{EC} 2$ & 0.812 & & & \\
\hline & EC 3 & 0.769 & & & \\
\hline & EC4 & 0.808 & & & \\
\hline \multirow[t]{4}{*}{ Perceived benefits } & PB 1 & 0.826 & 0.816 & 0.882 & 0.651 \\
\hline & PB 2 & 0.783 & & & \\
\hline & PB3 & 0.811 & & & \\
\hline & PB4 & 0.806 & & & \\
\hline \multirow[t]{3}{*}{ Informational publicity } & IB1 & 0.836 & 0.729 & 0.857 & 0.667 \\
\hline & IB2 & 0.799 & & & \\
\hline & IB3 & 0.814 & & & \\
\hline \multirow[t]{4}{*}{ Purchase intention (PI) } & PI1 & 0.829 & 0.801 & 0.876 & 0.635 \\
\hline & PI2 & 0.786 & & & \\
\hline & P13 & 0.817 & & & \\
\hline & PI4 & 0.753 & & & \\
\hline \multirow[t]{3}{*}{ Purchase behavior $(\mathrm{PBe})$} & PBe1 & 0.899 & 0.725 & 0.873 & 0.711 \\
\hline & $\mathrm{PBe} 2$ & 0.852 & & & \\
\hline & $\mathrm{PBe} 3$ & 0.746 & & & \\
\hline
\end{tabular}


Table 3. Discriminant validity (Source: Author's own research)

\begin{tabular}{|c|c|c|c|c|c|c|c|c|c|}
\hline Construct & 1 & 2 & 3 & 4 & 5 & 6 & 7 & 8 & 9 \\
\hline A & 0.797 & & & & & & & & \\
\hline SN & 0.315 & 0.809 & & & & & & & \\
\hline PBC & 0.446 & 0.520 & 0.815 & & & & & & \\
\hline MN & 0.401 & 0.464 & 0.499 & 0.859 & & & & & \\
\hline EC & 0.416 & 0.508 & 0.514 & 0.459 & 0.809 & & & & \\
\hline IP & 0.602 & 0.643 & 0.508 & 0.511 & 0.606 & 0.817 & & & \\
\hline PB & 0.416 & 0.524 & 0.506 & 0.603 & 0.646 & 0.705 & 0.806 & & \\
\hline $\mathrm{P} 1$ & 0.524 & 0.595 & 0.621 & 0.575 & 0.429 & 0.558 & 0.602 & 0.797 & \\
\hline $\mathrm{PBe}$ & 0.493 & 0.508 & 0.482 & 0.445 & 0.518 & 0.526 & 0.599 & 0.530 & 0.843 \\
\hline
\end{tabular}

The measurement model was used to examine the relationship between the latent variables and their measures, and the structural model was used to test the relationship between the latent variables. Firstly, evaluation of the measurement model was done by the examination of item loadings of the constructs. Hair, et al. (2019) recommended that loadings above 0.708 should be retained and values below this figure should be deleted. The next stage is the use of composite reliability to assess the internal consistency of measures, and values between 0.79 and 0.90 are acceptable. An additional measure of internal consistency is the Cronbach's alpha, and values of 0.70 and above are acceptable (Nunally and Bernstein, 1994). This stage is followed by the examination of the convergent validity of each construct by using the average variance extracted (AVE). The recommended minimum AVE is 0.50 . Also, the square roots of the AVEs should be greater than the correlations amongst variables.

The results as presented in Tables 2 and 3 which show that all items except for one under subjective norms have loadings above 0.708 and were retained. The composite reliability values for the constructs ranged between 0.792 and 0.884 . In addition, the Cronbach's alphas for all the constructs ranged between 0.726 and 0.808 , indicating a satisfactory internal consistency of measures. This implies an acceptable level of construct validity. The AVEs ranged between 0.635 and 0.737 , suggesting a good convergent validity of the scales. Furthermore, the square roots of AVEs are depicted on the diagonals and are all greater than the corresponding correlation coefficients within the constructs (Table 3). It can be concluded that the measurement model is satisfactory.

\subsection{Structural model assessment}

The assessment of the structural model includes common method bias (CMB), $\mathrm{R}^{2}, \mathrm{Q}^{2}$, and evaluation of the path coefficients (Hair, et al., 2019). The likelihood of CMB was examined as the data was self-reported. CMD can be identified through the variance inflation factors (VIFs) that are obtained through a full collinearity test. VIFs that are greater than 3.3 indicate pathological collinearity, and it is a signal that a model may be contaminated by CMB. However, if the VIFs are equal to or lower than 3.3, the model can be assumed to be free of CMB (Henseler, et al., 2015). The VIFs for the constructs of the study ranged from 1.205 to 2.482 , suggesting that the model is free of CMD. $\mathrm{R}^{2}$ shows the proportion of variance in the dependent variable that can be explained by the independent variable. $\mathrm{R}^{2}$ values are 0.25 (weak), 0.50 (moderate), and 0.75 (substantial) (Kock, 2015).

This study obtained an $\mathrm{R}^{2}$ of 0.707 , implying that the total variance of purchase intention that is explained 
by the model is $70.7 \%$. To determine if the model adequately explains the empirical data, the goodness-offit (GOF) test was used. The values of GOF range from 0 to 1 , with 0.10 considered small, 0.25 medium, and 0.36 large. The GOF is 0.687 , suggesting that the empirical data satisfactorily fits the model and has a good predictive power in comparison to baseline values. In addition to the size of $\mathrm{R}^{2}$, a recommended test is the predictive relevance of the model $\left(\mathrm{Q}^{2}\right)$. The two prediction techniques for $\mathrm{Q}^{2}$ are cross-validated communality and cross-validated redundancy, with Chin (2010) suggesting the use of the former.
$\mathrm{A} \mathrm{Q}^{2}>0.5$ is considered a predictive model and a $\mathrm{Q}^{2}$ of 0.69 obtained in this study is indicative of a highly predictive model. The effect size $\left(\mathrm{f}^{2}\right)$ shows the effect of one construct on another construct and the values are 0.02 (small), 0.15 (medium), and 0.35 (large). The effect size, $\mathrm{f}^{2}$, ranged from 0.026 to 0.131 , indicating that the effect sizes of different endogenous constructs on the exogenous constructs ranged from small to medium. The results path coefficients and Tstatistics of the T-statistics using the bootstrapping technique are depicted in Table 4.

Table 4. Path coefficient and T-statistics (Source: Author's own research)

\begin{tabular}{|c|c|c|c|}
\hline Hypothesized path & Standardized Beta & T-statistics & Decision \\
\hline H1: A to P1 & 0.136 & $3.042^{* *}$ & Accepted \\
\hline H2: SN to PI & 0.029 & 1.129 & Rejected \\
\hline H3: PBC to PI & 0.188 & $3.886^{*}$ & Accepted \\
\hline H4: MN to P1 & 0.135 & $3.648^{* *}$ & Accepted \\
\hline H5: EC to PI & 0.117 & $2.912^{* *}$ & Accepted \\
\hline H6: IP to PI & 0.128 & $3.321^{*}$ & Accepted \\
\hline H7: PB to P1 & 0.148 & $2.991^{* *}$ & Accepted \\
\hline H8: PI to PBe & 0.253 & $3.385^{* *}$ & Accepted \\
\hline$* p<0.01 ; * * p<0.05$ & & \\
\hline
\end{tabular}

Hypothesis $\mathrm{H} 1$ proposes that attitude (A) is positively related to purchase intention (PI). The results $(\beta=$ $0.136, \mathrm{~T}=3.042, \mathrm{p}<0.05)$ show a significant positive relationship between A and PI. H1 is accepted.

Hypothesis $\mathrm{H} 2$ proposes that subjective norms (SNs) are positively related to PI. The results $(\beta=0.029, \mathrm{~T}$ $=1.129, \mathrm{p}>0.05)$ depict an insignificant relationship between SNs and PI. H2 is rejected.

Hypothesis $\mathrm{H} 3$ proposes that perceived behavioral control (PBC) is positively related to PI. The results $(\beta=0.188, \mathrm{~T}=3.886, \mathrm{p}<0.01)$ show a significant relationship between PBC and PI. H3 is accepted.

Hypothesis $\mathrm{H} 4$ proposes that there is a significant positive relationship between moral norms (MNs) and PI. The results $(\beta=0.135, \mathrm{~T}=3.648, \mathrm{p}<0.05)$ support a significant positive relationship between attitude and MN and PI. H4 is accepted.

Hypothesis $\mathrm{H} 5$ proposes that environmental concern (EC) is positively related to PI. The results $(\beta=0.117$, $\mathrm{T}=2.912, \mathrm{p}<0.05)$ show a significant relationship between EC and PI. H5 is accepted.

Hypothesis $\mathrm{H} 6$ proposes that informational publicity (IP) is positively related to PI. The results ( $\beta=0.128$, $\mathrm{T}=3.321, \mathrm{p}<0.01)$ support a significant positive relationship between IP and PI. H6 is accepted.

Hypothesis $\mathrm{H} 7$ proposes that there is a significant positive relationship between perceived benefits (PB) and PI. The results $(\beta=0.148, T=2.991, p<0.05)$ support a significant positive relationship between PB and PI. $\mathrm{H} 7$ is accepted. 
Hypothesis $\mathrm{H} 8$ proposes that there is a significant positive relationship between purchase intention (PI) and purchase behavior $(\mathrm{PBe})$. The results $(\beta=0.253, \mathrm{~T}=$ $3.385, \mathrm{p}<0.05$ ) support a significant positive relationship between PI and PBe. H8 is accepted.

\section{Discussion}

The study examined the predictors of EEA purchase intention in South Africa by extending the TPB. In addition, in line with the TPB, the study investigated the effect of purchase intention on purchase behavior. The findings indicated that attitude has a significant positive relationship with EEA purchase intention. Young consumers with a positive attitude toward the use of EEAs are more likely to buy EEAs. The findings support the TPB model that attitude is a predictor of behavioral intention.

The findings are consistent with the results of previous empirical studies (Dickinger and Kleijnen, 2008; Wang, et al., 2019; Akroush, et al., 2019) which showed that the attitude toward an energy-efficient product has a strong effect on the intention to purchase. The findings showed that subjective norms do not have a significant impact on the intention to purchase EEAs. This is contrary to the original TPB model. Armitage and Conner (2001), in a meta-analysis of studies on the TPB and sustainability, found that attitudes and perceived behavioral control are better predictors of behavior than subjective norm, which tends to vary considerably across behaviors and situations. Empirical studies (Arvola, et al., 2008; Tan, et al., 2017) also find that SNs do not have a significant positive relationship with the purchase intention of EEAs.

The lack of a relationship suggests that young customers may not be easily influenced by the opinions of people close to them about their decisions to purchase EEAs. Perceived behavioral control (PBC) has a significant positive relationship with EEA purchase intention. Sung and Wang (2019) and Ali, et al. (2019) found that PBC positively affects consumers' intentions to purchase green products. Hua and Wang (2019) reported that the availability of knowledge and skill in respect of EEA should positively influence the intention to purchase. The results indicated that moral norms (MNs) positively affect EEA purchase intention.

Bhutto, et al. (2019) remarked that young customers are mostly educated and have perceived responsibilities to act morally in pro-environmental situations. Young people are environmentally and socially conscious customers and have grown up in a world where climate change is part of the daily discourse. Petschnig, et al. (2014) and Shalender and Sharma (2019) found that moral norms significantly influence the intention to purchase environmentally friendly products. In addition, Tan, et al. (2017) found that moral norms have a significant positive effect on consumers' purchase intention to purchase EEAs. The findings revealed a significant positive relationship between environmental concern (EC) and EEA purchase intention.

Young consumers are more concerned about the environment and climate change than ever and are imbibing sustainable lifestyles and consumption. Studies such as Kim and Han (2010), Aman, et al. (2012), Yadak and Pathak (2016), and Li, et al. (2019) reported that environmental concern is positively correlated with the willingness to purchase eco-friendly products including energy-efficient appliances. The findings revealed a significant positive relationship between informational publicity (EC) and EEA purchase intention. Environmental awareness through information publicity by the media influences individuals, businesses and governments about the negative effect of climate change. Wang, et al. (2014) reported that information publicity positively affects behavioral intention toward green products. According to Chen, et al. (2018), the media can facilitate the sharing of detailed information and promote the recognition of green products.

The results indicated that the perceived benefits are a significant predictor of the intention to purchase EEA. Hidrue, et al. (2011), Nosi, et al. (2018) and Akroush, et al. (2019) found that perceived benefits can positively affect the willingness to purchase environmentally friendly products. The findings revealed that consumers' purchase intention positively impacts on the purchase behaviour of EEAs. According to the TPB, the purchase intention of consumers is an essential indicator for predicting actual purchase. The findings of this study are consistent with similar empirical 
studies (Kumar, et al., 2017; Jaiswal and Kant, 2018; Bhutto, et al., 2019) in that there is a significant positive relationship between purchase intention and purchase behavior of environmentally friendly products.

\section{Conclusion}

South Africa is one of the least energy-efficient nations in the world, and its reliability on electricity supply is under threat. Household appliances are the biggest contributor to household energy consumption, and around $70 \%$ of household carbon dioxide emissions come from household appliances. One of the ways to reduce emissions and conserve energy is to increase the purchase and use of EEAs. The study investigated the factors that influence the purchase of energy efficient appliances by young consumers in South Africa. Young consumers (university students) are expected to drive sustainable consumption in the future.

Theoretically, the study extended the TPB by adding both individual and situational factors to develop a model of EEA purchase intention from the South African perspective. Empirically, the study deepens the knowledge on the factors that influence EEA purchase intention. The study has some practical implications, and the findings of the study can assist both policy-makers and the business to better comprehend how to promote EEAs. The findings revealed that perceived behavioral control, perceived benefits and informational publicity are significant predictors of purchase intention.

Therefore, the government and manufacturers of appliances should create awareness and enhance the knowledge on the benefits of EEAs through the media. Print, electronic, and social media and road shows can help to create awareness about the benefits of EEAs. The findings of the study also showed that environmental concern and moral norms significantly influence purchase intention. Government, non-governmental bodies and media locally and internationally should intensify awareness campaigns about the negative effects of climate change and the need to protect the environment.

The study has some limitations. The use of the nonprobability sampling method may lead to respondent bias. Data was collected from only two universities and this limits the generalizability of the findings of this study. Other studies should examine the moderating effects of demographic variables on purchase intention. In addition, the effect of energy efficiency labels on the purchase intention of EEAs can be investigated.

\section{$7 \quad$ References}

[1] Ahamad, N., Ariffin, M., 2018. Assessment of Knowledge, Attitude and Practice Towards Sustainable Consumption Among University Students in Selangor, Malaysia. Sustainable Production and Consumption, 16, pp.88-98.

[2] Aman, A.H.L., Harun, A., Hussein, Z., 2012. The Influence of Environmental Knowledge and Concern on Green Purchase Intention the Role of Attitude as a Mediating Variable. British Journal of Arts and Social Sciences, 7(2), pp.145-167.

[3] Fishbein M., Ajzen I., 1975. Belief, Attitude, Intention, and Behaviour: An Introduction to Theory and Research. Reading, MA: AddisonWesley.

[4] Ajzen, I., 1991. The Theory of Planned Behaviour. Organizational Behaviour and Human Decision Processes. 50(2), pp.179-211.

[5] Akroush, M., Zuriekat, M., Jabali, H., Asfour, N., 2019. Determinants of Purchasing Intentions of Energy-Efficient Products: The Roles of Energy Awareness and Perceived Benefits. International Journal of Energy Sector Management 13(1), pp.128-148.

[6] Ali, S., Ullah, H., Akbar, M., Aktar, W., Zahid, H. 2019. Determinants of Consumer Intentions to Purchase Energy-Saving Household Products in Pakistan. Sustainability. 11(5), pp.1462;

[7] Arvola, A., Vassallo, M., Dean, M., Lampila, P., Saba, A., Lähteenmäki, L., Shepherd, R., 2008. Predicting Intentions to Purchase Organic Food: The Role of Affective and Moral Attitudes in the Theory of Planned Behaviour. Appetite, 50(2), pp.443-454.

[8] Ayub, A., Naziman, Y., Samat, M. 2018. Factors Influencing Young Consumers' Purchase Intention of Organic Food Product. Advances in Business Research International Journal, pp.1-26. 
[9] Bauer, D., Arnold, J., Kremer, K., 2018. Consumption-Intention Formation in Education for Sustainable Development: An Adapted Model Based on the Theory of Planned Behaviour. Sustainability, 10(10), 3455, https://doi.org/10.3390/ su10103455.

[10] Bhutto, M., Zeng, Y., Soomro, F., Ali, Y., Ali, M., 2019. Young Chinese Consumer Decision Making in Buying Green Products: An Application of Theory of Planned Behaviour with Gender and Price Transparency, Pakistan Journal of Commerce and Social Sciences, 13(3), pp.599619.

[11] Chan, L., Bishop, B., 2013. A moral basis for recycling: Extending the theory of planned behaviour. Journal of Environmental Psychology, 36, pp.96-102.

[12] Chen, M., Tung, P., 2014. Developing an Extended Theory of Planned Behaviour Model to Predict Consumers' Intention to Visit Green Hotels. International Journal of Hospitality Management, 36, pp.221-230.

[13] Chen, C., Chen, C., Tung, Y., 2018. Exploring the Consumer Behaviour of Intention to Purchase Green Products in Belt and Road Countries: An Empirical Analysis. Sustainability, 10, pp.854.

[14] Chin, W.W., 1998. The Partial Least Squares Approach for Structural Equation Modeling. In: G. A., Marcoulides (Ed.). Methodology for Business and Management. Modern Methods for Business Research.. Lawrence Erlbaum Associates Publishers, p.295-336.

[15] Chin, W.W., 2010. How to Write up and Report PLS Analyses. In: V., Esposito Vinzi, W.W. Chin, J., Henseler and H., Wang (Eds.) Handbook of Partial Least Squares: Concepts, Methods and Applications (pp.655-690). Berlin: SpringerVerlag.

[16] Choi, D., Han, T., 2019. Green Practices among Fashion Manufacturers: Relationship with Cultural Innovativeness and Perceived Benefits. Social Sciences, 8(5), pp.1-16.

[17] Choudhury, D., Dey, A., 2014. Online Shopping Attitude Among the Youth: a Study on University Students. International Journal of Entrepreneurship and Development Studies, 2(1), pp.23-32.
[18] Chaudhary, R., Bisai, S., 2018. Factors Influencing Green Purchase Behaviour of Millennials in India. Management of Environmental Quality: An International Journal, 29(5), pp.798-812.

[19] Dagher, G., Itani, O., 2012. The Influence of Environmental Attitude, Environmental Concern and Social Influence on Green Purchasing Behaviour. Review of Business Research, 12(2), pp.104110.

[20] Dickinger, A., Kleijnen, M., 2008. Coupons Going Wireless: Determinants of Consumer Intentions to Redeem Mobile Coupons. Journal Interactive Marketing, 22(3), pp.23-40.

[21] D'Agostin' A., Medeiros, J., Vidor, G., Zulpo, M., Moretto, C., 2020. Drivers and Barriers for the Adoption of Use-Oriented Product-Service Systems: A Study with Young Consumers in Medium and Small Cities. Sustainable Production and Consumption, 21, pp.92-103.

[22] Department of Energy, 2019. South African Energy Sector Report. [online] Available at: http://www.energy.gov.za/files/media/explained /2018-South-African-Energy-Sector-Report.pdf https://www.iea.org/news/energy-efficient-prosperity-the-first-fuel-of-economic-development (Accessed 20 October 2019).

[23] Dunlap, R.E., Jones, R., 2002. Environmental Concern: Conceptual and Measurement Issues. In: R.E., Dunlap \& W., Michelson (Eds.). Handbook of Environmental Sociology (pp.482-542). Westport, CT: Greenwood Press

[24] du Plessis, W., 2015. Energy Efficiency and the Law: A Multidisciplinary Approach. South African Journal of Science, 111(1/2), pp.1-8.

[25] Environmental and Energy Study Institute, 2019. Energy Efficiency. [online] Available at https://www.eesi.org/topics/energy-efficiency /description (Accessed 20 October 2019).

[26] Fishbein M., Ajzen, I., 1975. Belief, Attitude, Intention, and Behaviour: An Introduction to Theory and Research. Reading, MA: AddisonWesley.

[27] Frederiks, E., Stenner, K,, Hobman, E., 2015. The Socio-Demographic and Psychological Predictors of Residential Energy Consumption: A Comprehensive Review. Energies. 8(1), pp.573-609. 
[28] Goh, Y.N., Wahid, N.A., 2014. A Review on Green Purchase Behaviour Trend of Malaysian Consumers. Asian Social Science, 11(2), pp.103110.

[29] Ha, H.Y., Janda, S., 2014. The Effect of Customized Information on Online Purchase Intentions. Internet Research, 24(4), pp.496-519.

[30] Hair, J.F., Risher J.J., Sarsstedt, M., Ringle, C.M., 2019. When to Use and How to Report the Results of PLS-SEM. European Business Review, 31, pp.2-24.

[31] Harris, P., 2006. Environmental Perspectives and Behaviour in China. Environment and Behaviour, 38(1), pp.5-21.

[32] Henseler, J., Ringle, C.M., Sarstedt, M. 2015. A New Criterion for Assessing Discriminant Validity in Variance-Based Structural Equation Modelling. Journal of the Academy of Marketing Science, 43(1), pp.115-135.

[33] Hidrue, M., Parsons, G., Kempton, W., Gardner, M., 2011. Willingness to Pay for Electric Vehicles and Their Attributes. Research and Energy Economics, 33, pp.686-705.

[34] Huang, X.Q.; Ge, J.P., 2019. Electric Vehicle Development in Beijing: An Analysis of Consumer Purchase Intention. Journal of Cleaner Production, 216, pp.361-372.

[35] Hua, L., Wang, S., 2019. Antecedents of Consumers' Intention to Purchase Energy-Efficient Appliances: An Empirical Study Based on the Technology Acceptance Model and Theory of Planned Behaviour. Sustainability. 11(10):2994, DOI: 10.3390/su11102994.

[36] International Energy Agency (IEA), 2016. Energy Efficient Prosperity: The "First Fuel" of Economic Development. https://www.iea.org/ news/energy-efficient-prosperity-the-first-fuelof-economic-development (Accessed 20 October 2019).

[37] International Energy Agency (2019). Global Energy Demand Rose by $2.3 \%$ in 2018, its Fastest Pace in the Last Decade. [online] Available at https://www.iea.org/newsroom/news/2019/mar ch/global-energy-demand-rose-by-23-in-2018its-fastest-pace-in-the-last-decade.html (Accessed 20 October 2019).
[38] Jaiswal, D., Kant, R., 2018. Green purchasing behaviour: A conceptual framework and empirical investigation of Indian consumers. Journal of Retailing and Consumer Services, 41, pp.60-69.

[39] Joshi, Y., Rahman, Z., 2015. Factors Affecting Green Purchase Behaviour and Future Research directions. International Strategic Management Review, 3(1/2), pp. 128-143.

[40] Kaiser, F.G., 2006. A Moral Extension of the Theory of Planned Behaviour: Norms and anticipated Feelings of Regret in Conservatism. Personality and Individual Differences, 41(1), pp.7181.

[41] Kanchanapibal, M., Lacka, E., Wang, X., Chan, H., 2014. An Empirical Investigation of Green Purchase Behaviour Among the Young Generation. Journal of Cleaner. Production, 66, pp.528536.

[42] Kim, Y., Han, H., 2010. Intention to Pay Conventional-Hotel Prices at a Green Hotel - a Modification of the Theory of Planned Behaviour. Journal of Sustainable Tourism, 18(8), pp.9971014.

[43] Kumar, B., Manrai, A., Manrai, L., 2017. Purchasing Behaviour for Environmentally sustainable Products: A Conceptual Framework and Empirical Study. Journal of Retailing and Consumer Services, 34, pp.1-9.

[44] Leung, Y., Rosenthal, S., 2019. Explicating Perceived Sustainability-Related Climate: A Situational Motivator of Pro-Environmental Behaviour, Sustainability, 11(1), pp.231.

[45] Li, G., Li, W., Jin, G., Wang, Z., 2019. Influence of Environmental Concern and Knowledge on Households' Willingness to Purchase Energy-Efficient Appliances: A Case Study in Shanxi, China. Sustainability, 11(4), pp.1073.

[46] López-Mosquera, N., García, T., Barrena, R., 2014. An extension of the Theory of Planned Behaviour to Predict Willingness to Pay for the Conservation of an Urban Park. Journal of. Environmental. Management. 135, pp.91-99.

[47] Manstead, A.S.R. 2000. The Role of Moral Norm in the Attitude-Behaviour Relationship. In: D.J., Terry \& M.A., Hogg (Eds.). Attitudes, Behaviour, and Social Context: The Role of Norms and 
Group Membership. Mahwah, NJ: Lawrence Erlbaum, pp.11-30.

[48] Maistry, N., McKay, T., 2016. Promoting energy Efficiency in a South African Universities. Journal of Energy in Southern Africa, 27(3), pp.1-10.

[49] Ng, M., Law, M., Zhang, S., 2018. Predicting Purchase Intention of Electric Vehicles in Hong Kong. Australian Marketing Journal, 26(3), pp.272-280.

[50] Nosi, C., Pucci, C., Silvestri, C., Aquilani, B., 2017. Does Value Co-Creation Really Matter? An Investigation of Italian Millennials Intention to Buy Electric Cars. Sustainability, 9(12):2159, DOI: $10.3390 /$ su9122159.

[51] Nunnally, J.C., Bernstein, I.H., 1994. Psychometric Theory. McGraw-Hill, New York.

[52] Pena-Cerezo, M., Artaraz-Minon, M., TejedorNunez, J., 2019. Analysis of the Consciousness of University Undergraduates for Sustainable Consumption. Sustainability, (11):4597, DOI: 10.3390/su11174597.

[53] Paddock, J., 2017. Household Consumption and Environmental Change: Rethinking the Policy Problem through Narratives of Food Practice. Journal of Consumer Culture, 17(1), pp.122-139. DOI: $10.1177 / 1469540515586869$.

[54] Qader, I., and Zainuddin, Y., 2011. The Impact of Media Exposure on Intention to Purchase Green Electronic Products amongst Lecturers. International Journal of Business and Management, 6(3), pp.240-249.

[55] Ramayah,, T., Lee, J., Mohamad, O., 2010. Green Product Purchase Intention: Some Insights from a Developing Country. Resources, Conservation and Recycling, 54 (12), pp.1419-1427.

[56] Rashid, N., Mohd, R., 2017. Customer's Purchase Intention for a Green Home'. International Journal of Procurement Management, 10(5), pp.581599.

[57] Ru, X., Wang, S., Yan, S., 2018. Exploring the Effects of Normative Factors and Perceived Behavioural Control on Individual's Energy-Saving Intention: An Empirical Study in Eastern China. Resource Conservation and Recycling, 134, pp.91-99.
[58] Shove, E., 2018. What is Wrong with Energy Efficiency? Building Research \& Information, 46(7), pp.779-789.

[59] Stadelmann, M., 2017. Mind the Gap? Critically Reviewing the Energy Efficiency Gap With Empirical Evidence. Energy Research \& Social Science, 27, pp.117-128.

[60] Statistics South Africa 2018. Electricity Generated and Available for Distribution, [online] Available at http://www.statssa.gov.za/publications/P4141/P4141June2018.pdf (Accessed 20 October 2019).

[61] Tan, C., Ooi, H., Goh, Y., 2017. A Moral Extension of the Theory of Planned Behaviour to Predict Consumers' Purchase Intention for EnergyEfficient Household Appliances in Malaysia. Energy Policy, 107, pp.459-471.

[62] Tholen, L., Gotz, T., Covary, T., Adisorn, T., 2015. The New South African Standards and Labelling Programme for Residential Appliances A First-Hand Evaluation Case Study. International Energy Policies \& Programmes Evaluation Conference, Amsterdam. https://energy-evaluation.org/wp-content/uploads/2019/06/2016-paper-gotz.pdf (Accessed 22 October 2019).

[63] United Nations, 2019. Sustainable Development Goals. [online] Available at https://www.un.org /development/desa/disabilities/envision2030 .html (Accessed 22 October 2019).

[64] Urban, J., Scasny, M., 2012. Exploring Domestic Energy-Saving: The Role of Environmental Concern and Background Variables. Energy Policy, 47, pp.69-80.

[65] Wang, Z., Zhang, B., Li, G., 2014. Determinants of Energy-Saving Behavioural Intention Among Residents in Beijing: Extending the Theory of Planned Behaviour, Journal of Renewable and Sustainable Energy, 6(5), https://doi.org/10.1063 /1.4898363.

[66] Wang, S., Fan, J., Zhao, D., Yang, S., 2016. Predicting Consumers' Intention to Adopt Hybrid Electric Vehicles: Using an Extended Version of the Theory of Planned Behaviour Model. Transportation, 43(1), pp.1-21.

[67] Wang, Z., Sun, Q., Wang, B., Zhang, B., 2019. Purchasing Intentions of Chinese Consumers on 
Energy-Efficient Appliances: Is the Energy Efficiency Label Effective? Journal of Cleaner Production, 238, pp.1-11.

[68] World Bank, 2019. Global Consumption Database. [online] Available at http://datatopics.worldbank.org/consumption/AboutDatabase. (Accessed 22 October 2019).

[69] World Energy Council, 2013. Energy Efficiency Policies - What Works and What Does Not. [online] Available at https://www.worldenergy.org/assets/downloads/World_Energy_Perspective_Energy-Efficiency-Policies-2013_Exe cutive Summary.pdf (Accessed 22 October 2019).
[70] World Economic Forum, 2018. Global Risks Report. [online] Available at https://www.weforum.org/reports/the-global-risks-report-2019 (Accessed 22 October 2019).

[71] World Wildlife Federation 2016. Living Planet Report 2016 Summary. [online] Available at

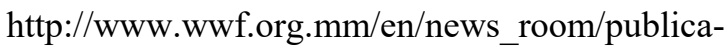
tions/?uNewsID=283110 (Accessed 22 October 2019).

[72] Yue, T., Long, R., Chen, H. 2013. Factors Influencing Energy-Saving Behaviour of Urban Households in Jiangsu Province. Energy Policy, 62(1), pp.665-675.

\section{Appendix A: Questionnaire}

\begin{tabular}{|c|c|c|c|}
\hline Concept & Survey items & $\begin{array}{l}\text { Response } \\
\text { category }\end{array}$ & Authors \\
\hline Attitude & $\begin{array}{l}\text { 1. I consider the purchase of energy-efficient ap- } \\
\text { pliances (EEAs) unfavorable (1)/favorable (5) } \\
\text { 2. I consider the purchase of EEA undesirable (1) } \\
\text { /desirable (5) } \\
\text { 3. I consider the purchase of EEA unpleasant (1) } \\
\text { /pleasant (5) } \\
\text { 4. I consider the purchase of EEA negative (1) } \\
\text { /positive (5) }\end{array}$ & $\begin{array}{l}\text { Semantic } \\
\text { differential scale }\end{array}$ & $\begin{array}{l}\text { Hua and Wang } \\
\text { (2019) } \\
\text { Akroush, et al. } \\
(2019)\end{array}$ \\
\hline $\begin{array}{l}\text { Subjective } \\
\text { norms }\end{array}$ & $\begin{array}{l}\text { 1. Most people who are important to me think I } \\
\text { should buy energy-efficient ones when it comes } \\
\text { to the choice of household appliances } \\
\text { 2. If I buy an EEA, this can influence other people } \\
\text { to buy an EEA } \\
\text { 3. People whose opinions I value would prefer } \\
\text { that I purchase EEAs }\end{array}$ & $\begin{array}{l}\text { Five-point Likert } \\
\text { scale with } 1 \text { being } \\
\text { "strongly disagree" } \\
\text { and } 5 \text { being } \\
\text { "strongly agree" }\end{array}$ & $\begin{array}{l}\text { Chen and Tung } \\
\text { (2014) } \\
\text { Tan, et al. (2017) }\end{array}$ \\
\hline $\begin{array}{l}\text { Perceived } \\
\text { behavioral } \\
\text { control }\end{array}$ & $\begin{array}{l}\text { 1. I can largely decide whether or not to buy } \\
\text { an EEA } \\
\text { 2. I will have the ability to buy an EEA in the fu- } \\
\text { ture } \\
\text { 3. I am confident that if I want to, I will definitely } \\
\text { be able to choose an EEA in the near future }\end{array}$ & $\begin{array}{l}\text { Five-point Likert } \\
\text { scale with } 1 \text { being } \\
\text { "strongly disagree" } \\
\text { and } 5 \text { being } \\
\text { "strongly agree" }\end{array}$ & Tan, et al. (2017) \\
\hline Moral norms & $\begin{array}{l}\text { 1. It is morally responsible to (other people } \\
\text { and/or) the environment for me to conserve } \\
\text { the natural resources } \\
\text { 2. It is my moral obligation to (other people } \\
\text { and/or) the environment for me to save natural } \\
\text { resources because they are limited } \\
\text { 3. It is my moral obligation to (other people } \\
\text { and/or) the environment for me to reduce } \\
\text { electricity usage }\end{array}$ & $\begin{array}{l}\text { Five-point Likert } \\
\text { scale with } 1 \text { being } \\
\text { "strongly disagree" } \\
\text { and } 5 \text { being } \\
\text { "strongly agree }\end{array}$ & $\begin{array}{l}\text { Tan, et al. (2017) } \\
\text { Shalender and } \\
\text { Sharma (2019) }\end{array}$ \\
\hline
\end{tabular}




\begin{tabular}{|c|c|c|c|}
\hline $\begin{array}{l}\text { Environmental } \\
\text { concern }\end{array}$ & $\begin{array}{l}\text { 1. I think the individuals and the society have } \\
\text { the responsibility to protect the environment } \\
\text { 2. I think the environmental issues are becoming } \\
\text { more serious in recent years } \\
\text { 3. I take into account environmental conse- } \\
\text { quences while I buy an appliance } \\
\text { 4. I think we should live in harmony with } \\
\text { the environment for achieving sustainable } \\
\text { development }\end{array}$ & $\begin{array}{l}\text { Five-point Likert } \\
\text { scale with } 1 \text { being } \\
\text { "strongly disagree" } \\
\text { and } 5 \text { being } \\
\text { "strongly agree }\end{array}$ & $\begin{array}{l}\text { Li, et al. (2019) } \\
\text { Shalender and } \\
\text { Sharma (2019) }\end{array}$ \\
\hline $\begin{array}{l}\text { Informational } \\
\text { publicity }\end{array}$ & $\begin{array}{l}\text { 1. Related informational publicity about climate } \\
\text { change and the environment promotes my } \\
\text { energy-saving behavior } \\
\text { 2. The information learned from newspapers, } \\
\text { television, and other media influences my } \\
\text { energy-saving behavior } \\
\text { 3. Informational publicity has encouraged me } \\
\text { to buy EEAs }\end{array}$ & $\begin{array}{l}\text { Five-point Likert } \\
\text { scale with } 1 \text { being } \\
\text { "strongly disagree", } \\
\text { and } 5 \text { being } \\
\text { "strongly agree }\end{array}$ & $\begin{array}{l}\text { Wang, et al. } \\
\text { (2014) }\end{array}$ \\
\hline $\begin{array}{l}\text { Perceived } \\
\text { benefits }\end{array}$ & $\begin{array}{l}\text { 1. EEAs give me extra value (e.g. economic } \\
\text { value, environmental value, and social value) } \\
\text { 2. EEAs have high utility } \\
\text { 3. EEAs can meet my product requirements } \\
\text { 4. I believe EEAs will save costs }\end{array}$ & $\begin{array}{l}\text { Five-point Likert } \\
\text { scale with } 1 \text { being } \\
\text { "strongly disagree" } \\
\text { and } 5 \text { being } \\
\text { "strongly agree" }\end{array}$ & $\begin{array}{l}\text { Wang, et al. } \\
(2017) \\
\text { Akroush, et al. } \\
(2019)\end{array}$ \\
\hline $\begin{array}{l}\text { Intention } \\
\text { to purchase }\end{array}$ & $\begin{array}{l}\text { 1. In the future, I am willing to buy EEAs if I } \\
\text { need to have home appliances } \\
\text { 2. In the future, I plan to buy appliances with } \\
\text { better energy efficiency } \\
\text { 3. In the future, I intend to buy appliances with } \\
\text { better energy efficiency }\end{array}$ & $\begin{array}{l}\text { Five-point Likert } \\
\text { scale with } 1 \text { being } \\
\text { "strongly disagree", } \\
\text { and } 5 \text { being } \\
\text { "strongly agree" }\end{array}$ & $\begin{array}{l}\text { Wang, et al. } \\
(2017) \\
\text { Akroush, et al. } \\
(2019)\end{array}$ \\
\hline $\begin{array}{l}\text { Purchase } \\
\text { behavior }\end{array}$ & $\begin{array}{l}\text { 1. I have purchased EEAs in the past } \\
\text { 2. I currently use EEAs } \\
\text { 3. Purchasing EEAs makes me feel that I have } \\
\text { played a great part in helping the environment }\end{array}$ & $\begin{array}{l}\text { Five-point Likert } \\
\text { scale with } 1 \text { being } \\
\text { "strongly disagree" } \\
\text { and } 5 \text { being } \\
\text { "strongly agree" }\end{array}$ & $\begin{array}{l}\text { Jaiswal and Kant } \\
\text { (2018) } \\
\text { Chaudhary and } \\
\text { Bisai (2018) } \\
\text { Bhutto, et al. } \\
\text { (2018) }\end{array}$ \\
\hline
\end{tabular}

